Article

\title{
The Impact of Project Organizational Culture on the Performance of Construction Projects
}

\author{
Luong Hai Nguyen ${ }^{1, *}$ and Tsunemi Watanabe ${ }^{2}$ \\ 1 Department of Construction Economics, University of Transport and Communications, No.3 Cau Giay Str., \\ Lang Thuong Ward, Dong Da Dist., Hanoi 100000, Vietnam \\ 2 Department of Management, School of Economics \& Management, Kochi University of Technology, \\ 2-22 Eikokuji-cho, Kochi 780-8515, Japan; watanabe.tsunemi@kochi-tech.ac.jp \\ * Correspondence: hainl.utc@gmail.com
}

Academic Editor: Marc A. Rosen

Received: 28 March 2017; Accepted: 30 April 2017; Published: 9 May 2017

\begin{abstract}
Cultural influence has recently received significant attention from academics due to its vital role in the success or failure of a project. In the construction industry, several empirical investigations have examined the influence of culture on project management. The aim of this study is to determine the impact of project organizational culture on the performance of construction projects. A total of 199 completed construction projects in Vietnam with specific data gathering through questionnaires were analyzed. The findings reveal that contractor commitment to contract agreements is the most significant cultural factor affecting project performance. Goal alignment and reliance, contractor commitment, and worker orientation (i.e., commitment to workers) contribute to improved overall performance and participant satisfaction. Contractor commitment and cooperative orientation enhance labor productivity, whereas goal alignment and trust and contractor commitment ensure learning performance (i.e., learning from experience). The findings of this study may assist construction professionals in implementing practices that can contribute to the sustainability and success of construction projects.
\end{abstract}

Keywords: project organizational culture; cultural influence; project performance; performance; project management; sustainability

\section{Introduction}

Construction project performance has been reported by literature with the following critical problems being found: poor quality, over budget, missing timeliness, unsafe construction and client dissatisfaction [1-4]. The factors that potentially influence the success or failure of construction projects must be identified to improve project performance.

A number of studies conducted to identify Critical Success Factors (CSFs) of construction projects have been conducted over the years [5-8]. Sanvido et al. [9] define the variables that determine project success. These factors are described in the literature as critical success or failure factors [6]. In the above-referenced literature, CSFs relevant to construction project management can be classified into five core clusters: (1) project management mechanisms [7,10-13]; (2) project-related factors [8,10-12,14-16], which focus on the project type, the nature and complexity of the project and the size of the project; (3) the external environment [7,11-14], which includes factors such as economic, social, and political issues and advances in physical tools and technology; (4) procurement approaches [7,15-18]; and (5) project culture $[7,11,19-25]$. To ensure that organizational goals are reached, management should pay constant and careful attention to CSF areas [6], which implies that, to improve construction project performance, it is essential to understand each of these factors and to investigate how they mutually interact and influence performance outcomes. Many studies related to each of these factors 
have been conducted in this field, and they have yielded valuable insights. Among these studies, notable examples include Proverbs et al. [26], Moselhi et al. [27], Cserháti and Szabó [12], and Mir and Pinnington [28].

Culture is viewed as an essential determinant of management practice; thus, culture has recently been examined in the literature as a CSF of construction project [29-31]. In addition, construction project organization is operated by multiple individuals with diversity of backgrounds, causing different human behavior and different expectations for a project. Hence, those involved individuals who come with complicated behaviors and/or attitudes significantly influence the success of project. It is also believed that cultural differences can generate conflicts relating to individual communication, which decline capacity of construction organizations to achieve project objectives [32,33]. It could therefore be argued that culture plays a vital role in the success or failure of project management. Thus, in practice of project management, culture should be treated as a significant aspect in controlling conflicts, improving quality outcomes, and encouraging innovation. Although organizational culture is recognized as influencing performance, it is the least-studied area in the construction management literature. Thus, studies that have been expected to enhance project performance have focused less on project organizational culture than on procurement approaches or project characteristics. Among the few studies that attempt to investigate the impact of project culture, Kumaraswamy et al. [34] suggest a framework to explain and analyze the cultural foundations of construction projects. In this framework, a typical project culture is derived from four overlapping groups of sub-cultures: organizational sub-cultures, operational sub-cultures, professional sub-cultures, and individualistic sub-cultures. Thomas et al. [35] employ the standard competing values framework model and the instrument developed by Cameron and Quinn [36] to assess the project culture of thirteen Australian construction projects. The results indicate that clan-type cultures (i.e., family-like cultures with a focus on mentoring, nurturing, and "doing things together") are positively correlated with quality outcomes, whereas market cultures (i.e., results-oriented cultures with a focus on competition, achievement, and "getting the job done"), which are more common in construction projects, are found to be negatively correlated with quality outcomes. The authors thus suggest that construction project culture be shifted from the currently prevalent market culture to a clan culture [35]. The authors also argue that a project culture should be designed to align the goals and objectives of the organization with those of the individual participants. This design helps reduce conflicts, enhance communication and coordination, and increase the ease with which project objectives are achieved. Zuo et al. [37] adapt existing organizational dimensions to propose five dimensions for a project culture model: integrative, cooperative, goal-oriented, flexible, and people-oriented. Their model focuses on relationships in contract procurement in the Chinese construction industry, and the findings indicate that there are medium-to-large positive correlations between all five dimensions of project culture and all indicators of project performance, namely, satisfaction with project success, commercial success, future business opportunities, and satisfaction with relationships with other parties. The majority of these correlations are positive; the exceptions are goal orientation and flexibility, which exhibit negative correlations with most of the project performance indicators. The results reveal that project culture contributes to improved project performance. More recently, Stare [38] investigated the influence of project organizational culture on project performance in Slovenian enterprises. His model of project organizational culture focuses more on the attitudes of top and line management in a wide range of business enterprises (i.e., IT, product development, and civil engineering), and despite the high level of project organizational culture observed, this result was relatively surprising given the generally poor project performance (almost 90 percent of the projects exceeded the planned time and costs). The most influential factors for project performance were the attitude of top management and the presence of clear priorities for projects.

Summarizing the above review, although research regarding the phenomenon of culture and its effects on performance in particular could inform cultural change, such research has thus far been disparate and inadequate. The nature of the implied relationships between project organizational 
culture and performance remain blurred. An insufficient number of studies have focused on identifying detailed culture dimensions at the project level within the construction industry context and finding empirical evidence for the influence of culture. As a result, the theory of organizational behavior, which examines what people do in an organization and how their behavior affects the organization's performance [39], has not yet been addressed at the project level. Nevertheless, the questions of what project organizational culture is and the nature of the relationship between culture and performance at the project level clearly remain unanswered in the context of the construction industry and deserve further investigation. Therefore, this study aims to fill this research gap. For this study, the hypothesis is as follows:

Hypothesis 1 (H1). Project organizational culture positively affects construction project performance.

\section{Justification for the Study Design}

\subsection{Project Organizational Culture and Its Identifiers}

The construction project organization can be defined as an organization, which can be said to be the pattern of interrelationships, authority and responsibility that is established between the contributors (i.e., client, supervision and contractor) to achieve the construction client's objectives [40]. As such, an adaptation of the existing knowledge of organizational culture is justifiable in defining the project organizational culture.

Although culture has been studied at different levels with regard to national culture, business culture, and organizational culture, which has been studied widely, there is still no agreement on a standard definition of the term. Most of the definitions of organizational culture contain elements regarding basic assumptions [41], values and norms [42], beliefs [42], and mental programs [43,44]. Moreover, organizational culture is defined as artifacts [45], manners of behaving [22,42], and work practices [45]. The divergence of those definitions was also indicated by Smircich [46], who noted that the organizational culture concept has indeed been derived from anthropology. Hence, because there is no agreement regarding the meaning of culture in anthropology, it is not surprising that there is also a multiplicity of definitions and applications in the field of organizational studies. Culture manifestations are either largely invisible or very visible to individuals. The intangible aspects comprise values, beliefs and underlying assumptions [41,47], whereas the tangible aspects encompass artifacts, creations and behavior norms [41], which are referred to as "practices" by Hofstede et al. [44]. Taken together, values and practices are considered two sides of culture. According to Hofstede et al. [44], values are defined as the individual's personal preferences in work and life-related issues, whereas practices are defined as descriptive perceptions by the employee of aspects of the work environment or actual work situation. As such, these descriptions make culture becomes more readily readable.

For years, several studies have analyzed culture based on values and basic assumptions. Although values and basic assumptions are critical aspects of organizational culture, it has been argued that organizations differ more in work practices than in values [44,45]. Moreover, it has been argued that values can be measured from work practices because significant aspects of values are often apparent from organizational practices [44,48]. This perspective was also supported by the agreement that the conventional view of culture, which concentrated on notions of shared values and beliefs, was inadequate; instead, organizational culture should be considered from strongly operational perspective "as embodied in the organization's structures, mechanisms and practices" [49]. These operational aspects characterize culture in action and are more credible reflections of the organization's culture than statements of values and beliefs, which may be out of step with culture as implemented [49]. Taken together, these arguments reinforce the notion that consistent and widespread practices are reflections of organizational culture [50]. It is beneficial to approach culture from the perspective of organizational practices because practices are more readily observable and measurable and can thus be compared across organizations and can be directly related to individual 
and organizational performance [50]. This approach is also consistent with Fellows and Liu [51], who argued that behavior provides the active and dynamic expressions of culture and therefore provides data through which culture may be studied. From the perspective of work practices, Kostova [52] defines organizational culture as "particular ways of conducting organizational functions that evolved over time.... [These] practices reflect the shared knowledge and competence of the organization". Van den Berg and Wilderom [48] define organizational culture as a shared perception of organizational work practices within organizational units that may differ from others. In the domain of project management, the numerous CSFs that have been explored include factors associated with managerial support, communication, relationships, participant involvement, and decision making $[5,6,11,53]$, all of which may be considered "cultural" factors that relate to the attitudes and behavior of participants in the project delivery process. Indeed, such factors are also considered determinants of the organizational culture construct in the management and organizational behavior literature $[39,54]$. As a result, the current study adopts a work practice-based approach to define project organizational culture in the following manner, based on the definitions offered by Kostova [52] and van den Berg and Wilderom [48]: the set of behaviors or attitudes observed in perceptions of practices shared by project participants in particular ways that help explain or resolve the problems encountered during the course of a project. From this perspective of cultural identification, project participants' behavior is the key factor in determining culture within project organizations. The culture differences are believed to generate differences in participant behavior, potentially resulting misunderstandings between individual involved, which can in turn create conflict and dissatisfaction among participants of a construction project. Measuring cultural artifacts is thus expected to involve examining the level of project participants' behavior.

Dimensions are widely used in describing organizational culture because of their flexibility to reflect the value being assessed [31]. To identify each project's organizational culture, it was therefore necessary to examine the sources of those dimensions. Cultural dimensions are rooted in fundamental problems that a group of people must address or for which they must find solutions [41,47]. Pinto [55] reveals four ways that organizational culture can affect project management. First, it affects how departments are expected to interact and support each other in the pursuit of project goals. Second, the culture influences the level of employee commitment to project goals in the context of balancing them with other potentially competing goals. Third, the organizational culture influences project planning processes such as the way that work is estimated or resources are assigned to projects. Finally, the culture affects how managers evaluate the performance of project teams and how they view project outcomes. Thus, when examining the dimensions of construction project organizational culture, one could argue that a useful source of information is the fundamental practices experienced by project participants during project delivery.

Subsequently, models for organizational culture were reviewed for the compilation of a list of cultural artifacts. From the perspective of the definition of project organizational culture, it is proposed that project organizational culture can be identified by adapting these artifacts to relevant participants' behaviors during the course of a project. Although there are commonly diverse project stakeholders (i.e., owners, users, clients, designer consultants, supervisors, and contractors), the targeted cultural artifacts are developed through continuous collaboration among key members (i.e., clients, supervisors and contractors). In this study, those three key project participants of a project organization are thus highlighted as actors involved in transforming culture at the project level. Table 1 presents a long list of 29 cultural artifacts summarized from various perspectives adopted by different researchers. 
Table 1. Artifacts of project organizational culture.

\begin{tabular}{|c|c|}
\hline Cultural Artifacts & Related References \\
\hline Clarifying of project objectives & {$[56,57]$} \\
\hline Roles and obligations of contractor & [58-61] \\
\hline Roles and obligations of client & [58-61] \\
\hline Shared understanding & [58-61] \\
\hline Project benefits commitment & {$[43]$} \\
\hline Effective working interactions & {$[56,62]$} \\
\hline Information exchanging & {$[36,63]$} \\
\hline Encouraging of project manager & {$[64]$} \\
\hline Mutual reliance & {$[58,65]$} \\
\hline Mutual respect and openness & {$[62,64]$} \\
\hline Exchange of ideas and support & {$[61,63]$} \\
\hline Assigning of blame and accountability & {$[47]$} \\
\hline Value of people's contributions & {$[47,57,66,67]$} \\
\hline Available opportunities & {$[62,68]$} \\
\hline Empowering assignments & {$[69]$} \\
\hline Recognition of achievements & [69] \\
\hline Training sessions & {$[13,56]$} \\
\hline Respect for workers & {$[62]$} \\
\hline Concern for workers & {$[62]$} \\
\hline Contractor commitment to quality & {$[56,70]$} \\
\hline Contractor commitment to schedule & {$[71]$} \\
\hline Contractor commitment to budget & {$[70]$} \\
\hline Supervisor commitment to work & [12] \\
\hline Client commitment to agreements & [16] \\
\hline Leaders' leadership & {$[2,56]$} \\
\hline Encouragement of decision-making & [2] \\
\hline Direction of leaders & {$[24,56]$} \\
\hline Guidance of leaders & {$[72-74]$} \\
\hline Involvement in decision processing & [36] \\
\hline
\end{tabular}

\subsection{Project Performance Measurement}

At present in the construction industry, systematic methods of performance measurement have influenced many construction firms, government sectors, public and private clients and other project stakeholders. Performance measurement refers to the regular collection and reporting of information about the inputs, efficiency and effectiveness of construction projects. Two models developed to measure construction project performance are the Integrated Performance Index [75] and Key Performance Indicators [71]. The Integrated Performance Index was developed by Pillai et al. [75] to measure the performance of R\&D projects, while Key Performance Indicators (KPIs) are the UK construction industry's response to Egan's report [71] and measure project performance based on 10 identified parameters. These parameters consist of seven project performance indicators (construction cost, construction time, cost predictability (design and construction), time predictability (design and construction), defects, client satisfaction with the product and client satisfaction with the service) and three company performance indicators (safety, profitability and productivity). The use of such indicators to evaluate organizational performance is very common [31]. Many industries employ industry-specific KPI systems to measure process performance that is critical to the success of an organization. Notwithstanding their popularity, KPIs seem to be more appropriate for assessing performance at the project level [76]. As a result, in this study, the KPIs are adapted with needing to consider the accessibility of data collection because of the multifaceted project's outcome $[24,77,78]$. This method of determining performance indicators is considered a reasonable approach to assess the performance quality and success of a project $[79,80]$.

Among the performance measures that indicate the success of a project, cost, time and quality are generally considered to be the most vital performance indicators for construction 
projects $[12,13,28,81,82]$. Several researchers have suggested that safety should be added to the list of construction project performance indicators [12,83-85]. Furthermore, performance should not only be singularly assessed by the achievement of measurable benefits but also assessed by considering the effectiveness of contractors in sustaining performance improvements, such as their profitability $[24,86]$, productivity of labor $[4,87]$, and learning from experience [88]. These performance indicators are used to measure project performance, and the most important indicators are viewed as the KPIs of construction projects. The performance measurement indexes adopted in this study are described in Table 2.

Table 2. Proposed performance indicators.

\begin{tabular}{cc}
\hline Performance Indicators Employed & References \\
\hline Client satisfaction with quality & {$[8,10,13,25,81,82]$} \\
Client satisfaction with timeliness & {$[7,8,10,12,81,82,87]$} \\
Client satisfaction with cost & {$[7,8,12,81,82]$} \\
Client satisfaction with safety issues & {$[8,12,83-85,89]$} \\
Satisfaction with profitability & {$[4,24,28,86,90]$} \\
Labor productivity & {$[4,87,91]$} \\
Lessons learned & {$[78,87,92,93]$} \\
Overall performance & {$[94]$} \\
\hline
\end{tabular}

\section{Research Methods}

\subsection{Sampling and Data Collection}

Case-specific data collection was conducted from practitioners who were involved with construction projects in Vietnam and serve in the role of project manager for clients and contractors. This approach was adopted because the two key project participants in the course of a construction project are considered the seller (contractor) and the buyer (client), who is involved directly or indirectly (through representatives such as designer consultants and supervisors) in the production process of the seller. Clients and contractors with positions of project leaders, managing directors, and senior engineers were approached after consultation for a pilot study to determine that they had sufficient information to complete the required questionnaire items. A total of 416 participants were randomly selected to answer questionnaires. The face-to-face interviews and email were the main tools used in collecting information for the study. Follow-up telephone calls were also supported tool to remind and urge the participants to reply to the questionnaires. Participants were asked to respond to the survey questions based on the most recently completed project in which they were involved. A total of 265 answers were received, and 199 responses qualified for investigation, which represents an effective rate of $47.8 \%$.

Amongst the 199 valid samples, $84.9 \%$ of respondents were contractors and $15.1 \%$ remaining were clients. Regarding respondents' background, $79.5 \%$ of the respondents were project managers and $20.5 \%$ were project engineers (i.e., with responsibilities as project managers). Furthermore, $79 \%$ of the respondents had more than five years of experience in project management. Regarding the types of projects, $55.5 \%$ of the projects were infrastructure systems (roads, bridges, and water systems), $39.5 \%$ of the projects were buildings (apartments, commercial, and offices), and $5 \%$ of the projects were industrial and factory facilities. Regarding the scale of projects, $25.6 \%$ of the projects were big investment (national level), $59.2 \%$ of projects were medium investment (the budget $>15$ billionVND) and $15.2 \%$ were small scale. Among those projects surveyed, $54 \%$ were funded by Vietnamese government, $24.3 \%$ were invested by private sectors and $21.7 \%$ were financed by foreign countries.

\subsection{Measures}

The questionnaire items were divided into three sections. In the first section, respondents were asked to provide their demographic characteristics and a description of the features of their projects. 
The remaining sections aimed to collect the data required for the variables in the research model, including cultural artifacts and project performance indicators. The survey required each respondent to assess his or her experience in a recently completed construction project using a five-point Likert scale that ranged from one (strongly disagree/not at all satisfied) to five (strongly agree/extremely satisfied). The questionnaire was first prepared in English and then translated into Vietnamese, which necessitated certain changes to the survey due to the classical and modern forms of the Vietnamese language. In particular, it was difficult to translate project management phrases from English to Vietnamese (e.g., "performance" and "project organizational culture"). Moreover, any changes to the survey had to be correctly translated before its official distribution to respondents. The questions were then modified to generate the most precise answers.

Principal component factor analysis (PCFA) was carried out to examine the factor structure of the cultural artifacts. PCFA is an effective tool for demonstrating convergent and discriminant validity and for reducing the number of variables to be considered in subsequent analyses [95]. Additionally, verification for the reliability of the factorized artifacts was undertaken by using Cronbach's alpha [96]. The range of alpha value is from 0 to 1 ; the higher the alpha value is, the more reliable the groupings of artifacts are. A Cronbach's alpha value that is higher than 0.7 is considered as "good" and/or "acceptable" in reliability testing $[96,97]$.

The stepwise method is frequently used to decide which independent variables should be used in a regression model and how such variables should be incorporated into the model. Although the main value of stepwise selection is that it can be used to select a subset of explanatory variables based on statistical criteria, several recent studies have emphasized the limitations of stepwise selection, including the lack of stability of the set of selected variables and the bias in parameter estimates [98]. This method also subsequently ignores both the variables that are not selected and the uncertainty caused by the variable selection procedure $[99,100]$. Bayesian model averaging (BMA) is thus applied in this study. The BMA approach selects a number of possible models and uses the posterior probabilities of these models to perform all inferences and predictions. The frequency of selection of BMA is greater than that of stepwise selection. In many cases, BMA also provides smaller standard deviations for parameter estimates [98]. The BMA method selects the correct model and outperforms the stepwise approach in predicting events of interest $[99,100]$.

\section{Results and Discussions}

\subsection{Factors in Project Organizational Culture (Project Culture)}

PCFA was employed to identify a smaller factor (i.e., called "principal components", from the set of 29 cultural artifacts, which principally reduce the number of variable factors and avoid multicollinearity. The eigenvalue, which is commonly used to establish a cutoff, is most reliable when the number of artifacts is between 20 and 50 [95]. Because the number of artifacts in this study is 29 , the use of the eigenvalue criterion was appropriate. Factors with eigenvalues greater than or equal to 1 were considered significant.

The results of the PCFA (Table 3) using the Kaiser-Meyer-Olkin (KMO) measure of sampling adequacy and Bartlett's test show that the data are suitable for factor analysis. The KMO value is 0.924, which is above the suggested threshold of 0.6 [31]. The low significance of Bartlett's test also satisfies the requirements [95]. Factor loadings with the threshold of above 0.4 were considered [12,101]. The final factor loading matrices show that the five culture components that were initially extracted account for $62.488 \%$ of the total variance in the 29 cultural artifacts, which indicates that those extracted artifacts can help to explain project organizational culture [96]. The range of Cronbach's alpha values varies from 0.658 to 0.900 , which is considered acceptable internal consistency reliability of all extracted factors [12]. 
Table 3. Factors of cultural artifacts.

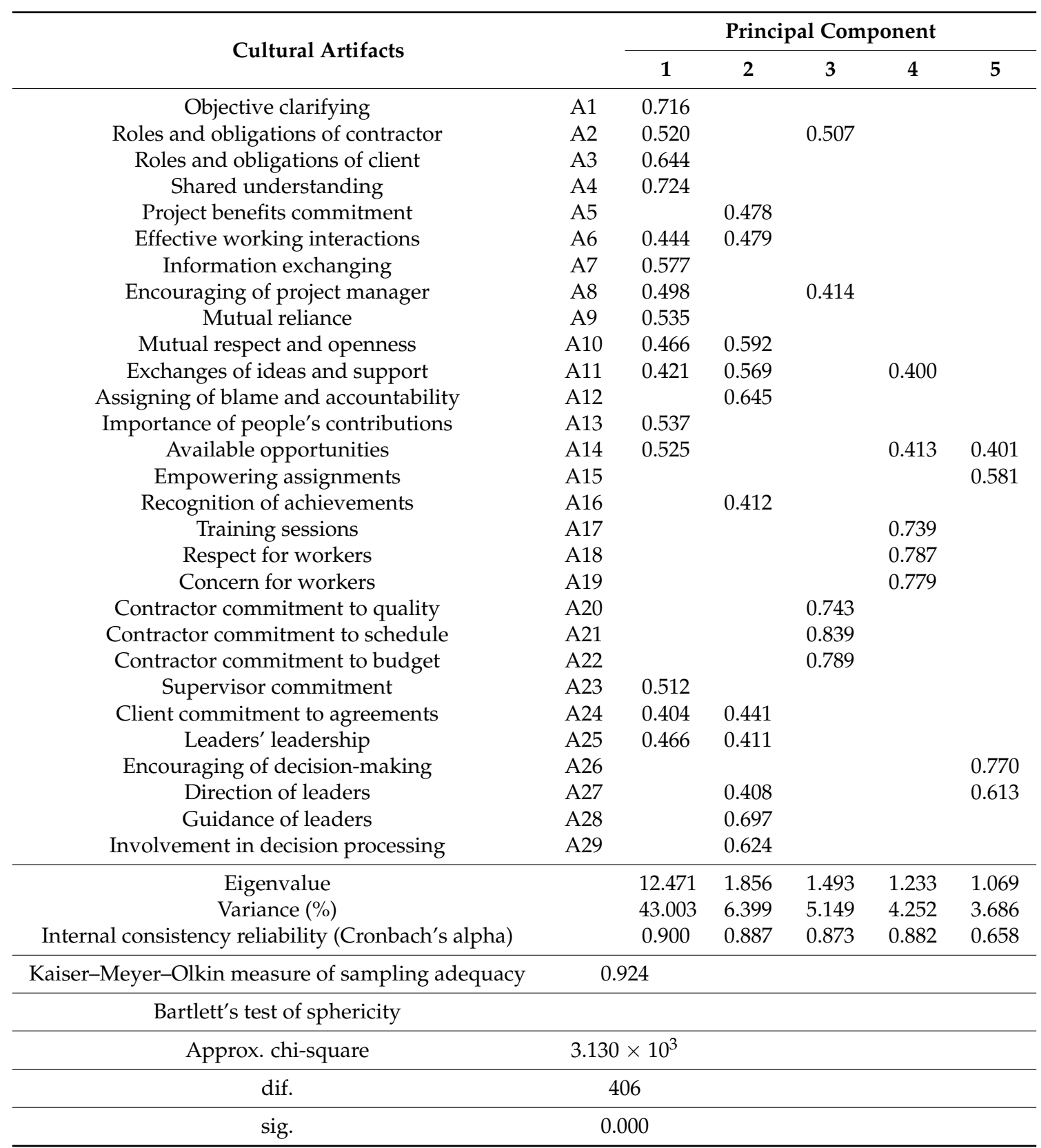

Eleven artifacts were extracted as significant in cultural factor 1: (i) objective clarifying; (ii) the roles and obligations of the contractor; (iii) the roles and obligations of the client; (iv) shared understanding; (v) information exchanging; (vi) encouraging of project manager; (vii) mutual reliance; (viii) the value of people's contributions; (ix) available opportunities; (x) supervisor commitment; and (xi) leaders' leadership. Considering the artifact descriptions provided in Table 3, artifacts (i-iii) can be used to assess the effectiveness of goal clarifying in the course of project. The remaining items in cultural factor 1 can be used to evaluate the degree that people are reliable to achieve project goals. This culture factor is called goal alignment and reliance.

Cultural factor 2 comprises nine items: (i) project benefits commitment; (ii) effective working interactions; (iii) openness and mutual respect; (iv) exchanges of ideas and support; (v) assigning blame and accountability; (vi) recognition of achievements; (vii) client commitment to agreements; (viii) guidance of leaders; and (ix) involvement in decision processing. The concepts of artifacts 
extracted in factor 2 contribute to generate the cooperation of working environment. Thus, cultural factor 2 is called cooperative orientation.

Three items are loaded significantly in cultural factor 3: (i) contractor commitment to quality; (ii) contractor commitment to schedule; and (iii) contractor commitment to budget. These artifacts associate with the degree that contractor is committed to project outcomes. Thus, this cultural factor is labeled contractor commitment.

Cultural factor 4 is called worker orientation and comprises three artifacts relate to the extent to which the workforce is concerned: (i) training sessions; (ii) respect for workers; and (iii) concern for workers.

The taxonomy of factor 5 comprises three items: (i) empowering assignments; (ii) encouragement of decision-making; and (iii) direction of leaders. This cultural factor is called empowerment orientation because the extracted items relate to the level at which empowered individuals are involved in making decisions regarding the achievement of the project goals.

In summary, the following five factors of project organizational culture for the construction industry are identified from the principal component factor analysis: (i) goal alignment and reliance; (ii) cooperative orientation; (iii) contractor commitment; (iv) worker orientation; and (v) empowerment orientation, which are expected to form a construction project organizational culture framework in the industry.

To rank these culture dimensions, factor scores were calculated based on the average mean scores of each factor's artifacts. The project organizational culture factors were then ranked in descending order based on their scores, as shown in Table 4.

Table 4. Significance scores of project organizational culture dimensions.

\begin{tabular}{|c|c|c|c|}
\hline No. & Value Dimensions & Cultural Artifacts & Score (Ranking) \\
\hline 1 & Goal alignment and reliance $(\mathrm{C} 1)$ & $\begin{array}{l}\text { Objective clarifying } \\
\text { Roles and obligations of contractor } \\
\text { Roles and obligations of client } \\
\text { Shared understanding } \\
\text { Information exchanging } \\
\text { Encouraging of project manager } \\
\text { Mutual reliance } \\
\text { Value of people's contributions } \\
\text { Available opportunities } \\
\text { Supervisor commitment } \\
\text { Leaders' leadership }\end{array}$ & $3.75(1)$ \\
\hline 2 & Contractor commitment (C2) & $\begin{array}{l}\text { Contractor commitment to quality } \\
\text { Contractor commitment to schedule } \\
\text { Contractor commitment to budget }\end{array}$ & $3.53(2)$ \\
\hline 3 & Cooperative orientation (C3) & $\begin{array}{l}\text { Project benefits commitment } \\
\text { Effective working interactions } \\
\text { Openness and mutual respect } \\
\text { Exchanges of ideas and support } \\
\text { Accountability and assignment of blame } \\
\text { Recognition of achievements } \\
\text { Client commitment to agreements } \\
\text { Leaders' instruction } \\
\text { Involvement in decision making }\end{array}$ & $3.40(3)$ \\
\hline 4 & Empowerment orientation (C4) & $\begin{array}{l}\text { Empowering assignments } \\
\text { Encouragement of decision making } \\
\text { Leaders' direction }\end{array}$ & $3.30(4)$ \\
\hline 5 & Worker orientation (C5) & $\begin{array}{l}\text { Training sessions } \\
\text { Respect for workers } \\
\text { Concern for workers }\end{array}$ & $3.03(5)$ \\
\hline
\end{tabular}


The significance scores of these five factors can be roughly divided into three groups: the top two (above 3.50), the next two (between 3.30 and 3.40) and the last one (just above 3.00). Based on a scale of five, these scores indicate that the factors are above-average identifiers of project organizational culture in the construction industry.

The first group, "goal alignment and reliance", was ranked highest. This finding is consistent with that of Cheung et al. [102], who find that "goal setting and accomplishment" has the highest score among organizational culture dimensions in the construction industry. This finding clearly supports the notion that a project organization is identified by its culture, which in turn is determined by the goals that are set, manifested by the approach taken and crystallized by the actions implemented by the organization. In other words, clear goals instruct the formulation of strategies and an action plan. Unless these goals are changed, the actions that may be taken by the organization to achieve its goals are believed to be consistent and predictable. In addition, the development of trust and mutual understanding engender harmony among participants, which reduces risk for all involved parties and builds relationships that establish a rapport among participants before the project implementation phase [18]. The second-highest ranked factor is "contractor commitment". The relatively high ranking of this project organizational culture factor aptly reflects the emphasis placed on contractor commitment in construction project organizations.

The second group comprises two factors with similar organizational culture factor scores: cooperative orientation and empowerment orientation. Due to the fragmented nature of the construction industry, a highly cooperative orientation characterized by the free exchange of ideas, coordination, and the sharing of accountability among construction project members is often a prerequisite for project success. By cooperating, project participants aim to reduce overall project costs, share project risks and rewards, and increase mutual profits $[103,104]$. Furthermore, by empowering employees to speak up and be heard, organizations are "using their greatest asset to its highest potential and, in return, are becoming more competitive in the emerging global economy [105]." In organizations without employee empowerment cultures, it may be inappropriate for employees to offer feedback or suggestions to management, despite the fact that such feedback improves performance.

The lowest-ranked factor is "worker orientation", which has a neutral score. This finding is not surprising and in fact reinforces Egan's [71] argument that the construction industry continues to fail to recognize that its workforce is its greatest asset, and hence there is a need to invest in training and development, health and safety, decent site conditions, and fair wages. This failure also encompasses a lack of concern for the environment and sustainability issues because these factors also relate to a concern for people, albeit people in society in general. It is not surprising that the construction industry has one of the worst industry records for health and safety and a poor record for recruitment and retention [106,107].

\subsection{Analysis of Variance (ANOVA)}

The contracting organizations in a construction project have different backgrounds and business objectives; thus, the representativeness of the identified project organizational culture factors may vary across contracting organizations. In this regard, analysis of variance (ANOVA) was conducted to determine whether there is a significant difference in the perceived significance of the identified project organizational culture factors between the two groups of respondents: clients and contractors. The results are summarized in Table 5 . The significance scores of the five project organizational culture factors are all greater than 3.0 on a 5-point Likert scale. This finding indicates that the two groups of respondents regard all of these factors as appropriate for identifying project organizational culture in construction. Furthermore, as indicated in Table 5, at a 99\% confidence level (i.e., at the $p<0.01$ level), the group differences in mean scores for the five project organizational culture factors are not significant. The ANOVA results of this study indicate that, despite their association with different types of organizations, there is no evidence to suggest that the two types of respondents have different views regarding project organizational culture in the construction industry. 
There is a general belief that, due to differences in business objectives, leadership styles, life cycles, and work patterns, the contracting organizations in construction may develop different cultures $[33,102]$. However, the ANOVA results do not reveal a significant difference between clients and contractors in terms of project organizational culture in the construction industry, as shown in Table 5. As such, both groups of respondents agreed that the five factors identified by the PCFA are valid measures of project organizational culture in the construction industry. The acceptance of these factors by the two groups of construction professionals suggests that the proposed framework can be used as a foundation for project organizational culture features in future investigations.

Table 5. Analysis of variance (ANOVA) results.

\begin{tabular}{|c|c|c|c|c|c|c|}
\hline & Statistics & $\begin{array}{c}\text { Goal } \\
\text { Alignment and } \\
\text { Reliance (C1) }\end{array}$ & $\begin{array}{l}\text { Contractor } \\
\text { Commitment } \\
\text { (C2) }\end{array}$ & $\begin{array}{l}\text { Cooperative } \\
\text { Orientation } \\
\text { (C3) }\end{array}$ & $\begin{array}{l}\text { Empowerment } \\
\text { Orientation } \\
\text { (C4) }\end{array}$ & $\begin{array}{l}\text { Worker } \\
\text { Orientation } \\
\text { (C5) }\end{array}$ \\
\hline Clients & Mean significance score & 3.83 & 3.34 & 3.53 & 3.42 & 3.14 \\
\hline \multirow{2}{*}{ Contractors } & Mean significance score & 3.75 & 3.57 & 3.38 & 3.28 & 3.02 \\
\hline & SD & 0.72 & 0.72 & 0.64 & 0.64 & 0.99 \\
\hline
\end{tabular}

\subsection{The Impact of Project Organizational Culture on Project Performance}

Multiple regression analyses were performed to test whether the cultural factors predicted project outcomes. The variables encompassed by the five dimensions of culture were included as predictors. The independent variables were the four performance indices mentioned above (Table 1): (i) participant satisfaction, which is extracted as a significant factor by PCFA based on the five sub-measurements (i.e., client satisfaction with quality, time, cost, safety issues and contractor satisfaction with profitability), and is also supported by the literature in the construction management domain [19,108,109]; (ii) labor productivity; (iii) lessons learned; and (iv) overall performance. The BMA method for variable selection was used and outputs (Table 6) were obtained. The results recommended the best models for the selected predictors. Here, the Bayesian information criteria (BIC) and the post-probability (post prob) methods have the highest absolute value and highest value, respectively.

Table 6. The Bayesian model averaging (BMA) of selection.

\begin{tabular}{ccccc}
\hline & $\begin{array}{c}\text { Participant } \\
\text { Satisfaction }\end{array}$ & $\begin{array}{c}\text { Labor } \\
\text { Productivity }\end{array}$ & Learning & $\begin{array}{c}\text { Overall } \\
\text { Performance }\end{array}$ \\
\hline Intercept & $0.633^{\mathrm{b}}$ & $1.044^{\mathrm{a}}$ & 0.391 & $0.656^{\mathrm{a}}$ \\
Goal alignment and reliance (C1) & $0.314^{\mathrm{a}}$ & & $0.550^{\mathrm{a}}$ & $0.328^{\mathrm{a}}$ \\
Contractor commitment (C2) & $0.362^{\mathrm{a}}$ & $0.353^{\mathrm{a}}$ & $0.254^{\mathrm{a}}$ & $0.335^{\mathrm{a}}$ \\
Cooperative orientation (C3) & & $0.289^{\mathrm{a}}$ & & \\
Empowerment orientation (C4) & & & & \\
Worker orientation (C5) & $0.109^{\mathrm{b}}$ & & & $0.105^{\mathrm{b}}$ \\
nVar & 3 & 2 & 2 & 3 \\
R-squared & 0.587 & 0.281 & 0.377 & 0.643 \\
BIC & -160.179 & -55.04 & -83.549 & -189.261 \\
Post prob & 0.491 & 0.475 & 0.744 & 0.556 \\
F-statistic & $92.45^{\mathrm{a}}$ & $38.29^{\mathrm{a}}$ & $59.28^{\mathrm{a}}$ & $117.2^{\mathrm{a}}$ \\
\hline & ${ }^{\mathrm{a}} p<0.001{ }^{\mathrm{b}} p<0.01$. & &
\end{tabular}

Table 6 shows that goal alignment and reliance (C1), contractor commitment (C2), and worker orientation (C5) are conducive to achieving better overall performance and participant satisfaction. The recommended models explain $64.3 \%$ and $58.7 \%$ of the variation in overall performance and participant satisfaction, respectively $(p<0.000)$. Labor productivity is influenced by contractor 
commitment (C2) and cooperative orientation (C3), which collectively explain $28.1 \%$ of the variation in labor productivity $(p<0.000)$. In addition, goal alignment and reliance (C1) and contractor commitment (C2) have a positive effect on learning performance, accounting for $37.7 \%$ of its variation $(p<0.000)$. The ANOVA, which tests whether a model is a useful predictor of project performance, provides significant results $(p<0.000)$, indicating that the recommended models significantly improve the prediction of project performance. In addition, the variance inflation factor (VIF) analysis is well below 10 (all VIFs were below 1.80), which indicates no multicollinearity within the data [101].

To assess the relative importance of regressors in the linear models, the quantification of the contribution of individual regressors to a multiple regression model is indicated. Each regressor's contribution is the $R^{2}$ from the univariate regression, and all univariate $R^{2}$ values add up to the total model $R^{2}$ [110]. The functionality of the $R$ package ("relaimpo") has been employed to assess the relative importance of linear models by offering a metric of LMG (R-squared partitioned by averaging over orders, as in Lindemann, Merenda and Gold) [110]. The results are presented in Table 7.

Table 7. Relative importance metrics.

\begin{tabular}{ccccc}
\hline Variables & $\begin{array}{c}\text { Participant } \\
\text { Satisfaction }\end{array}$ & $\begin{array}{c}\text { Labor } \\
\text { Productivity }\end{array}$ & Learning & $\begin{array}{c}\text { Overall } \\
\text { Performance }\end{array}$ \\
\hline Goal alignment and reliance (C1) & 0.182 & & 0.220 & 0.211 \\
Contractor commitment (C2) & 0.272 & 0.162 & 0.157 & 0.287 \\
Cooperative orientation (C) & & 0.119 & & \\
Empowerment orientation (C4) & 0.133 & & & 0.145 \\
$\quad$ Worker orientation (C5) & 0.587 & 0.281 & 0.377 & 0.643 \\
$\quad$ R-squared & & & & \\
\hline
\end{tabular}

The findings note that the three predictors (i.e., goal alignment and reliance (C1), contractor commitment (C2), and worker orientation (C5)) positively associate with both the project performance of participant satisfaction and overall outcome, which may specify that the higher the level of these predictors of projects, the higher the level of participant satisfaction and overall performance is. These findings do not support those of Zuo et al. [37], who find that a cooperative culture correlates with overall project performance. It may be that a cooperative culture is an efficient dynamic for the partnership approach, which is the focus in their study. However, taking the content of related factors into consideration, these correspondences are clarified. In the fulfillment of participant satisfaction as well as the overall outcome with the primary project objectives (i.e., satisfaction with quality, cost, time, safety, and profit), the commitment of the project members, their objective understanding, the clarification of roles and responsibilities, the mutual trust of participants, and worker orientation are essential areas. Similarly, Leung et al. [109] note that behavioral management issues, such as commitment, participation and goal commitment, can be significantly positively associated with participant satisfaction. In addition, a clear objective, the concept and feasibility of an event, the management of human resources, problem solving, the handling of relationships and good communication with stakeholders have been identified as key factors of the success of organizational event projects [12]. These primary project performance criteria can only be accomplished through a process of clear and objective sharing of roles and responsibilities, strong commitment, and employee orientation, by which project members know when and what they have to do and who can support their work because they are fully committed to the joint efforts. As such, a project team can acquire the knowledge necessary to perform an activity or solve a problem, which is crucial to the success of future projects [78].

The result also clarified that the culture of cooperative orientation can assist in enhancing labor productivity. This revelation is expected in the field of human resource management, where a cooperation environment is expected to create effective working relationships, openness and mutual respect, and exchanges of ideas and support, which are the main factors that positively influence 
workforce performance. In addition, the study findings were unconnected with the variables included in the cultural factor of empowerment orientation (C4). In general, the redundancy of empowerment orientation is somewhat surprising because this orientation promotes leadership culture [111], which is recognized in the project management literature $[68,112]$. This redundancy may be explained by the fact that an empowerment culture is inefficient when applied in a price-based (i.e., low-bid or traditional procurement) environment with a client who assumes a great deal of power in managing the project [2].

Moreover, the analysis in Table 7 indicates that the culture factor of contractor commitment (C2) plays the most significant effect on most project outcomes. The significant role of the contractor is consistent with the suggestion that the contractor has a significant influence on performance outcomes [11,19]. This revelation could also explain the significant impact of the contractor on the success of projects in the traditional procurement approach known as the low-bid system. This system is plagued by major issues, including project delays, budget overruns, poor customer satisfaction [3], poor productivity [71,113], poor safety and insufficient quality [91], and low contractor profit margins $[2,114]$. The present study indicates that participants' commitment to the course of a project could be the key factor in project success in the traditional procurement environment. To our knowledge, this is the first study to investigate the influence of project organizational culture on project outcomes in a context dominated by traditional procurement-driven projects.

In summary, the five-factor framework is more akin to Denison's model [56], which has been widely utilized for its explanatory value with respect to business organizations. Denison [56] states that an effective organization should include the four organizational culture traits of involvement, consistency, adaptability and mission; these traits are believed to influence the performance of business organizations. These concepts can be related to the findings of this study as follows.

Firstly, project organizational culture with the dimension of goal alignment (C1) can be associated with mission, vision and strategy and can provide everyone with a clear direction for their work during the course of a project. The dimension of cooperative orientation (C3) is amplified by a coordination and integration culture within which different functions and units of a project's organization can and do work together well; moreover, project members should understand the mutual impacts of the ways that they work and ensure that work is coordinated and integrated to serve the project organization as a whole and achieve common goals. This approach helps to engender internal consistency. Denison [56] argues that organizations with clear missions that emphasize internal consistency are stable.

In addition, the dimension of contractor commitment (C2) reflects a customer-focused culture within which it is believed that the contractor recognizes the need to react to and serve the client and continually seeks to meet the client's future needs and improve ways to satisfy client expectations. This culture orientation contributes to enabling the project organization to perceive and respond to the environment and the customer (i.e., the client) in a manner that allows the project organization to adapt appropriately.

Moreover, the dimension of empowerment (C4) culture provides opportunities to individuals to be authorized, initiative, and capable in organizing and administrating their own working responsibilities. Furthermore, individuals attain greater clarity regarding areas in which they have decision-making power, input, or no responsibilities. This phenomenon creates a sense of ownership and responsibility toward the project organization. While an emphasis on worker orientation (C5) reflects the culture of capability development within which the project organization is thought to continually invest in the development of employee skills to remain competitive and meet on-going business needs. Empowerment and capability development in combination with team orientation have been argued to foster high involvement among project members [56].

To this end, the five-factor project organizational culture framework presented in this study may be regarded as more practice-specific than frameworks that have previously been reported in construction-related studies in terms of application. This prior gap in the literature presents a major management challenge for project participants. 


\section{Contribution of This Research}

This investigation is the first study to provide insight into the definition and identification of organizational culture at the project level from a work practice-based perspective that reflects the shared knowledge and competence of a project organization during the course of a project. In addition, this study provides empirical evidence of significant associations between project organizational culture and construction project performance that may be indicative of a causal effect of culture. It contributes to validating a theory of organizational behavior by suggesting that people's behaviors affect organizational performance, an effect that has not been explored at the project level in prior literature.

These findings contribute to understanding project organizational culture and its impacts and can therefore help practitioners in the construction industry by providing guidance regarding how to identify key factors that affect construction project success and thereby ensure the appropriate allocation of limited resources. It would be illogical to devote resources to cultural change initiatives without any evidence of these initiatives' usefulness for improving project performance.

\section{Research Limitations and Future Research}

This study suffers from several limitations. First, the size of the sample was relatively small, which may affect the significance level of the moderating effect. Increasing the sample size may yield new revelations. Second, there was a lack of diversity among the respondents, who were overwhelmingly contractors $(85 \%)$. This lack of stakeholder diversity may limit the perspective(s) offered by this particular study.

\section{Conclusions}

This study was carried out to better define project organizational culture and to detect a cultural framework, which was based upon the work practice approach that is characterized by the practices experienced during the course of a project. In this respect, artifacts of project organizational culture were first identified by adapting multiple models of organizational culture. Measurements of the experiences of construction practitioners in Vietnam were used in PCFA to categorize these artifacts into five organizational culture factors. The relative importance of these factors was evaluated based on their significance scores. This study identified no significant difference in the rankings provided by contracting organizations. In this regard, the proposed framework can be used as a foundation for utilizing project organizational culture features to explain variability in project performance. The two project organizational culture factors of "goal alignment and reliance" and "contractor commitment" highlight the result-focused and temporary characteristics of construction businesses. Moreover, the factor of "cooperative orientation" is needed to characterize the fragmentation and diverse participant involvement in construction project delivery. The factors of "empowerment orientation" and "worker orientation" reflect the fact that greater involvement among project members is associated with a greater sense of ownership and responsibility, leading to greater commitment to the project organization and an increased capacity for autonomy in the achievement of project goals. These cultures should be aware of project stakeholders in order to adhere to the proper structural design and management of project organizations.

Analyses of associations between those cultural factors and diverse project performance were then conducted, which shows that those cultural factors can predict different aspects of project performance (i.e., the developed models shown in Table 6). Four robust models were developed. The findings show that goal alignment and reliance, contractor commitment, and worker orientation contribute to better overall performance and participant satisfaction. Labor productivity can be predicted using only two cultural dimensions: contractor commitment and cooperative orientation. Goal alignment and trust and contractor commitment are more useful in predicting learning performance. The study verifies that the culture of contractor commitment plays the significant part of project outcomes. These findings on 
culture impacts imply that culture change must be prioritized on the list of effective tools to contribute to the sustainability and success of construction projects. This finding suggests that greater effort is needed to make cultural aspects part of the project procurement system.

Finally, further research is recommended to assess the motivations for cultural change in the construction industry. Such research will help governments to develop and implement a new scheme of project procurement system that is sustainable and innovative.

Acknowledgments: The authors acknowledge the participation of the individuals and organizations who contributed their professional experience and knowledge to this research during the field studies. Additionally, the authors would like to express their appreciation for the financial support provided by the Vietnamese government during the full term of this study.

Author Contributions: L.H.N. designed the research, conducted the survey in Vietnam and analyzed the data. T.W. contributed with research structure and analyses. L.H.N. wrote the paper.

Conflicts of Interest: The authors declare no conflict of interest. The founding sponsors had no role in the design of the study; in the collection, analyses, or interpretation of data; in the writing of the manuscript, and in the decision to publish the results.

\section{Appendix}

Please choose the most recently completed project on which you were personally involved and provide appropriate answers to the questions/or descriptions below.

Based on your experience on the project described, please specify the extent to which you agree that the following conditions and behaviors were present on site. Choose strongly agree only for those conditions that were consciously promoted on this project.

\begin{tabular}{|c|c|c|c|c|c|c|}
\hline \multirow[b]{2}{*}{ ID } & \multirow[b]{2}{*}{ Contents } & \multicolumn{5}{|l|}{ Answers } \\
\hline & & $\begin{array}{l}\text { 1. Strongly } \\
\text { Disagree }\end{array}$ & 2. Disagree & 3. Neutral & 4. Agree & $\begin{array}{l}\text { 5. Strongly } \\
\text { Agree }\end{array}$ \\
\hline \multicolumn{7}{|c|}{ A-The project organizational culture. } \\
\hline 1 & $\begin{array}{l}\text { All project participants on this project } \\
\text { shared a clear understanding of the } \\
\text { objectives and values of the project. }\end{array}$ & 1. $\square$ & 2. $\square$ & 3. $\square$ & 4. $\square$ & 5. $\square$ \\
\hline 2 & $\begin{array}{l}\text { The contractors on this project clearly } \\
\text { understood what roles and duties were } \\
\text { required of them. }\end{array}$ & 1. $\square$ & 2. $\square$ & 3. $\square$ & 4. $\square$ & 5. $\square$ \\
\hline 3 & $\begin{array}{l}\text { The client on this project clearly } \\
\text { understood what roles and duties } \\
\text { were required. }\end{array}$ & 1. $\square$ & 2. $\square$ & 3. $\square$ & 4. $\square$ & 5. $\square$ \\
\hline 4 & $\begin{array}{l}\text { All project participants understood } \\
\text { each other's objectives, expectations } \\
\text { and values. }\end{array}$ & 1. $\square$ & 2. $\square$ & 3. $\square$ & 4. $\square$ & 5. $\square$ \\
\hline 5 & $\begin{array}{l}\text { When disputes or conflicts occurred, } \\
\text { participants first looked to how the } \\
\text { project would benefit instead } \\
\text { themselves. }\end{array}$ & 1. $\square$ & 2. $\square$ & 3. $\square$ & 4. $\square$ & 5. $\square$ \\
\hline 6 & $\begin{array}{l}\text { There were effective working } \\
\text { relationships among the participants in } \\
\text { exploring innovative solutions and } \\
\text { bringing down costs and time. }\end{array}$ & 1. $\square$ & 2. $\square$ & 3. $\square$ & 4. $\square$ & 5. $\square$ \\
\hline 7 & $\begin{array}{l}\text { Information was shared, transparent, } \\
\text { and available for participants during } \\
\text { the course of the project. }\end{array}$ & 1. $\square$ & 2. $\square$ & 3. $\square$ & 4. $\square$ & 5. $\square$ \\
\hline 8 & $\begin{array}{l}\text { Project managers provided clear } \\
\text { communication, assistance and support } \\
\text { to their subordinates. }\end{array}$ & 1. $\square$ & 2. $\square$ & 3. $\square$ & 4. $\square$ & 5. $\square$ \\
\hline
\end{tabular}




\begin{tabular}{|c|c|c|c|c|c|c|}
\hline \multirow[b]{2}{*}{ ID } & \multirow[b]{2}{*}{ Contents } & \multicolumn{5}{|l|}{ Answers } \\
\hline & & $\begin{array}{l}\text { 1. Strongly } \\
\text { Disagree }\end{array}$ & 2. Disagree & 3. Neutral & 4. Agree & $\begin{array}{l}\text { 5. Strongly } \\
\text { Agree }\end{array}$ \\
\hline 9 & $\begin{array}{l}\text { A high level of mutual trust was shared } \\
\text { by the project participants. }\end{array}$ & 1. $\square$ & 2. $\square$ & 3. $\square$ & 4. $\square$ & 5. $\square$ \\
\hline 10 & $\begin{array}{l}\text { The participants were not consistently } \\
\text { open and respectful of each other. }\end{array}$ & 1. $\square$ & 2. $\square$ & 3. $\square$ & 4. $\square$ & 5. $\square$ \\
\hline 11 & $\begin{array}{l}\text { The participants were not really willing } \\
\text { to exchange ideas and help each other. }\end{array}$ & 1. $\square$ & 2. $\square$ & 3. $\square$ & 4. $\square$ & 5. $\square$ \\
\hline 12 & $\begin{array}{l}\text { Assigning blame and accountability } \\
\text { issues were very common when things } \\
\text { went wrong. }\end{array}$ & 1. $\square$ & 2. $\square$ & 3. $\square$ & 4. $\square$ & 5. $\square$ \\
\hline 13 & $\begin{array}{l}\text { All project participants were viewed } \\
\text { as important contributors to the } \\
\text { project's success. }\end{array}$ & 1. $\square$ & 2. $\square$ & 3. $\square$ & 4. $\square$ & 5. $\square$ \\
\hline 14 & $\begin{array}{l}\text { Opportunities were provided to } \\
\text { develop the capabilities of project } \\
\text { participants during the project process. }\end{array}$ & 1. $\square$ & 2. $\square$ & 3. $\square$ & 4. $\square$ & 5. $\square$ \\
\hline 15 & $\begin{array}{l}\text { Project participants were empowered } \\
\text { to make decisions at any level } \\
\text { by themselves. }\end{array}$ & 1. $\square$ & 2. $\square$ & 3. $\square$ & 4. $\square$ & 5. $\square$ \\
\hline 16 & $\begin{array}{l}\text { Project participants did not take pride } \\
\text { in or celebrate achievements when } \\
\text { achieving production milestones. }\end{array}$ & 1. $\square$ & 2. $\square$ & 3. $\square$ & 4. $\square$ & 5. $\square$ \\
\hline 17 & $\begin{array}{l}\text { Workers were not given the } \\
\text { opportunity to attend any training } \\
\text { sessions about skills and safety. }\end{array}$ & 1. $\square$ & 2. $\square$ & 3. $\square$ & 4. $\square$ & 5. $\square$ \\
\hline 18 & Workers were not really respected. & 1. $\square$ & 2. $\square$ & 3. $\square$ & 4. $\square$ & 5. $\square$ \\
\hline 19 & $\begin{array}{l}\text { Workers were not concerned about } \\
\text { health and welfare. }\end{array}$ & 1. $\square$ & 2. $\square$ & 3. $\square$ & 4. $\square$ & 5. $\square$ \\
\hline 20 & $\begin{array}{l}\text { The contractors shared a high degree of } \\
\text { commitment to making the project } \\
\text { successful with regard to quality. }\end{array}$ & 1. $\square$ & 2. $\square$ & 3. $\square$ & 4. $\square$ & 5. $\square$ \\
\hline 21 & $\begin{array}{l}\text { The contractors shared a high degree of } \\
\text { commitment to making the project } \\
\text { successful with regard to the schedule. }\end{array}$ & 1. $\square$ & 2. $\square$ & 3. $\square$ & 4. $\square$ & 5. $\square$ \\
\hline 22 & $\begin{array}{l}\text { The contractors shared a high degree of } \\
\text { commitment to making the project } \\
\text { successful with regard to contract costs. }\end{array}$ & 1. $\square$ & 2. $\square$ & 3. $\square$ & 4. $\square$ & 5. $\square$ \\
\hline 23 & $\begin{array}{l}\text { The supervisory consultants shared } \\
\text { a high degree of commitment to } \\
\text { making the project successful. }\end{array}$ & 1. $\square$ & 2. $\square$ & 3. $\square$ & 4. $\square$ & 5. $\square$ \\
\hline 24 & $\begin{array}{l}\text { The client shared a high degree } \\
\text { of commitment to the } \\
\text { contract agreements. }\end{array}$ & 1. $\square$ & 2. $\square$ & 3. $\square$ & 4. $\square$ & 5. $\square$ \\
\hline 25 & $\begin{array}{l}\text { Strong leadership was shown by those } \\
\text { who were project leaders. }\end{array}$ & 1. $\square$ & 2. $\square$ & 3. $\square$ & 4. $\square$ & 5. $\square$ \\
\hline 26 & $\begin{array}{l}\text { Decision-making was liberally } \\
\text { encouraged at every level. }\end{array}$ & 1. $\square$ & 2. $\square$ & 3. $\square$ & 4. $\square$ & 5. $\square$ \\
\hline 27 & $\begin{array}{l}\text { Leaders always made sure that their } \\
\text { subordinates knew what was } \\
\text { expected of them. }\end{array}$ & 1. $\square$ & 2. $\square$ & 3. $\square$ & 4. $\square$ & 5. $\square$ \\
\hline 28 & $\begin{array}{l}\text { Leaders did not always make sure that } \\
\text { individual accountability was clear. }\end{array}$ & 1. $\square$ & 2. $\square$ & 3. $\square$ & 4. $\square$ & 5. $\square$ \\
\hline 29 & $\begin{array}{l}\text { Everyone was not given the } \\
\text { opportunity to participate in the } \\
\text { decision making. }\end{array}$ & 1. $\square$ & 2. $\square$ & 3. $\square$ & 4. $\square$ & 5. $\square$ \\
\hline
\end{tabular}




\begin{tabular}{|c|c|c|c|c|c|c|}
\hline ID & Contents & Answers & & & & \\
\hline \multicolumn{7}{|c|}{ Please indicate the extent of satisfaction with each indicator of project performance below. } \\
\hline \multicolumn{2}{|c|}{ B-Project performance } & $\begin{array}{l}\text { 1. Not at all } \\
\text { satisfied }\end{array}$ & $\begin{array}{l}\text { 2. Slightly } \\
\text { satisfied }\end{array}$ & $\begin{array}{l}3 . \\
\text { Moderately } \\
\text { satisfied }\end{array}$ & $\begin{array}{l}\text { 4. Very } \\
\text { satisfied }\end{array}$ & $\begin{array}{l}\text { 5. Extremely } \\
\text { satisfied }\end{array}$ \\
\hline 30 & $\begin{array}{l}\text { The client was satisfied with the } \\
\text { project quality. }\end{array}$ & 1. $\square$ & 2. $\square$ & 3. $\square$ & 4. $\square$ & 5. $\square$ \\
\hline 31 & $\begin{array}{l}\text { The client was satisfied with the } \\
\text { project schedule. }\end{array}$ & 1. $\square$ & 2. $\square$ & 3. $\square$ & 4. $\square$ & 5. $\square$ \\
\hline 32 & $\begin{array}{l}\text { The client was satisfied with the } \\
\text { project cost. }\end{array}$ & 1. $\square$ & 2. $\square$ & 3. $\square$ & 4. $\square$ & 5. $\square$ \\
\hline 33 & $\begin{array}{l}\text { Safety and environmental conditions in } \\
\text { the course of project were satisfied. }\end{array}$ & 1. $\square$ & 2. $\square$ & 3. $\square$ & 4. $\square$ & 5. $\square$ \\
\hline \multirow[t]{2}{*}{34} & $\begin{array}{l}\text { How satisfied was the contractor with } \\
\text { the level of profitability of this project. }\end{array}$ & 1. $\square$ & 2. $\square$ & 3. $\square$ & 4. $\square$ & 5. $\square$ \\
\hline & & Very low & Low & neutral & High & Very high \\
\hline 35 & Rate the labor productivity. & 1. $\square$ & 2. $\square$ & 3. $\square$ & 4. $\square$ & 5. $\square$ \\
\hline 36 & $\begin{array}{l}\text { Rate the learning of the participants } \\
\text { from the project. }\end{array}$ & 1. $\square$ & 2. $\square$ & 3. $\square$ & 4. $\square$ & 5. $\square$ \\
\hline
\end{tabular}

\section{References}

1. Ibrahim, A.R.B.; Roy, M.H.; Ahmed, Z.; Imtiaz, G. An investigation of the status of the Malaysian construction industry. Benchmarking 2010, 17, 294-308. [CrossRef]

2. Kashiwagi, D.; Kashiwagi, J.; Smithwick, J.; Kashiwagi, I.; Kashiwagi, A. The source of degradation of the construction industry performance. J. Adv. Perform. Inf. Value 2012, 4, $206-222$.

3. Hai, N.L.; Watanabe, T. The status quo and perspective for improvement of public works procurement performance in Vietnam. J. Adv. Perform. Inf. Value 2014, 6, 22-39.

4. Xiong, B.; Skitmore, M.; Xia, B.; Masrom, M.A.; Ye, K.; Bridge, A. Examining the influence of participant performance factors on contractor satisfaction: A structural equation model. Int. J. Proj. Manag. 2014, 32, 482-491. [CrossRef]

5. Chan, A.P.C.; Scott, D.; Chan, A.P.L. Factors affecting the success of a construction project. J. Constr. Eng. Manag. 2004, 130, 153-155. [CrossRef]

6. Fortune, J.; White, D. Framing of project critical success factors by a systems model. Int. J. Proj. Manag. 2006, 24, 53-65. [CrossRef]

7. Garbharran, H.; Govender, J.; Msani, T. Critical success factors influencing project success in the construction industry. Acta Structilia 2012, 19, 90-108.

8. Alias, Z.; Zawawi, E.M.A.; Yusof, K.; Aris, N.M. Determining critical success factors of project management practice: A conceptual framework. Procedia Soc. Behav. Sci. 2014, 153, 61-69. [CrossRef]

9. Sanvido, V.; Grobler, F.; Parfitt, K.; Guvenis, M.; Coyle, M. Critical success factors for construction projects. J. Constr. Eng. Manag. 1992, 118, 94-111. [CrossRef]

10. Belout, A. Effects of human resource management on project effectiveness and success: Toward a new conceptual framework. Int. J. Proj. Manag. 1998, 16, 21-26. [CrossRef]

11. Chua, D.K.H.; Kog, Y.C.; Loh, P.K. Critical success factors for different project objectives. J. Constr. Eng. Manag. 1999, 125, 142-150. [CrossRef]

12. Cserháti, G.; Szabó, L. The relationship between success criteria and success factors in organisational event projects. Int. J. Proj. Manag. 2014, 32, 613-624. [CrossRef]

13. Davis, K. Different stakeholder groups and their perceptions of project success. Int. J. Proj. Manag. 2014, 32, 189-201. [CrossRef]

14. Akinsola, A.O.; Potts, K.F.; Ndekugri, I.; Harris, F.C. Identification and evaluation of factors influencing variations on building projects. Int. J. Proj. Manag. 1997, 15, 263-267. [CrossRef]

15. Kumaraswamy, M.M.; Chan, W. Factors facilitating faster construction. J. Constr. Procure. 1999, 5, 88-98. 
16. Omran, A.; Abdulbagei, M.A.; Gebril, A.O. An evaluation of the critical success factors for construction projects in Libya. Int. J. Econ. Behav. 2012, 2, 17-25.

17. Walker, D. Construction time performance and traditional versus non-traditional procurement methods. J. Constr. Procure. 1997, 3, 42-55.

18. Walker, D.H.T.; Rowlinson, S.M. Procurement Systems: A Cross-industry Project Management Perspective; Taylor \& Francis: New York, NY, USA, 2008.

19. Dozzi, S.P.; AbouRizk, S.M.; Schroeder, S.L. Utility-theory model for bid markup decisions. J. Constr. Eng. Manag. 1996, 122, 119-124. [CrossRef]

20. Fenn, P.; Lowe, D.; Speck, C. Conflict and dispute in construction. Constr. Manag. Econ. 1997, 15, 513-518. [CrossRef]

21. Phua, F.T.T.; Rowlinson, S. Cultural differences as an explanatory variable for adversarial attitudes in the construction industry: The case of Hong Kong. Constr. Manag. Econ. 2003, 21, 777-785. [CrossRef]

22. Mullins, L.J. Management and Organisational Behaviour; Financial Times Prentice Hall: New York, NY, USA, 2005.

23. Sage, D.; Dainty, A.; Brookes, N. A critical argument in favor of theoretical pluralism: Project failure and the many and varied limitations of project management. Int. J. Proj. Manag. 2014, 32, 544-555. [CrossRef]

24. Carvalho, M.M.D.; Patah, L.A.; Bido, D.D.S. Project management and its effects on project success: Cross-country and cross-industry comparisons. Int. J. Proj. Manag. 2015, 33, 1509-1522. [CrossRef]

25. Williams, P.; Ashill, N.J.; Naumann, E.; Jackson, E. Relationship quality and satisfaction: Customer-perceived success factors for on-time projects. Int. J. Proj. Manag. 2015, 33, 1836-1850. [CrossRef]

26. Proverbs, D.G.; Holt, G.D.; Olomolaiye, P.O. Productivity rates and construction methods for high rise concrete construction: A comparative evaluation of UK, German and French contractors. Constr. Manag. Econ. 1999, 17, 45-52. [CrossRef]

27. Moselhi, O.; Assem, I.; El-Rayes, K. Change orders impact on labor productivity. J. Constr. Eng. Manag. 2005, 131, 354-359. [CrossRef]

28. Mir, F.A.; Pinnington, A.H. Exploring the value of project management: Linking project management performance and project success. Int. J. Proj. Manag. 2014, 32, 202-217. [CrossRef]

29. Kwan, A.Y.; Ofori, G. Chinese culture and successful implementation of partnering in Singapore's construction industry. Constr. Manag. Econ. 2001, 19, 619-632. [CrossRef]

30. Walker, A. Project Management in Construction, 4th ed.; McGraw-Hill: New York, NY, USA, 2002.

31. Cheung, S.O.; Wong, P.S.P.; Lam, A.L. An investigation of the relationship between organizational culture and the performance of construction organizations. J. Bus. Econ. Manag. 2012, 13, 688-704. [CrossRef]

32. Tijhuis, W. Report-developments in construction culture research: Overview of activities of CIB W112 culture in construction. J. Quant. Surv. Constr. Bus. 2011, 1, 66-76.

33. Ankrah, N.A.; Langford, D.A. Architects and contractors: A comparative study of organizational cultures. Constr. Manag. Econ. 2005, 23, 595-607. [CrossRef]

34. Kumaraswamy, M.M.; Rowlinson, S.M.; Phua, F.T.T. Origins and Desired Destinations of Construction Project Cultures. In Proceedings of the CIB TG-23 Workshop on Culture in Construction, CIB World Congress, Wellington, New Zealand, 2-6 April 2001.

35. Thomas, R.; Marosszeky, M.; Karim, K.; Davis, S.; McGeorge, D. The Importance of Project Culture in Achieving Quality Outcomes in Construction. In Proceedings of the 10th Annual Conference International Group of Lean Construction, Gramado, Brazil, 6-8 August 2002.

36. Cameron, K.; Quinn, R. Diagnosing and Changing Organizational Culture; Prentice-Hall: Upper Saddle River, NJ, USA, 1999.

37. Zou, J.; Zillante, G.; Coffey, V. Project culture in the Chinese construction industry: Perceptions of contractors. Australas. J. Constr. Econ. Build. 2008, 9, 17-28. [CrossRef]

38. Stare, A. The impact of the organisational structure and project organisational culture on project performance in Slovenian enterprises. Manag. J. Contemp. Manag. Issues 2011, 16, 1-22.

39. Robbins, S.P.; Judge, T.A.; Millett, B.; Boyle, M. Organizational Behavior, 5th ed.; Pearson Higher Education: Melbourne, Australia, 2013.

40. Walker, A. Project Management in Construction, 6th ed.; John Wiley \& Sons, Ltd.: Chichester, UK, 2015.

41. Schein, E.H. Organizational Culture and Leadership; Jossey-Bass Publishers: San Francisco, CA, USA, 1985. 
42. Eldridge, J.E.T.; Crombie, A.D. A Sociology of Organisations; International Publications Service: New York, NY, USA, 1974.

43. Hofstede, G.H. Cultures and Organizations: Software of the Mind; McGraw-Hill: New York, NY, USA, 1997.

44. Hofstede, G.; Hofstede, G.J.; Minkov, M. Cultures and Organizations: Software of the Mind, 3rd ed.; McGraw-Hill Education: New York, NY, USA, 2010.

45. Khan, I.U.; Usoro, A.; Majewski, G. An organisational culture model for comparative studies and assessment of IT projects. Int. J. Hum. Cap. Inf. Technol. Prof. 2012, 3, 63-83. [CrossRef]

46. Smircich, L. Concepts of culture and organizational analysis. Adm. Sci. Q. 1983, 28, 339-358. [CrossRef]

47. Hofstede, G. Culture's Consequences: Comparing Values, Behaviors, Institutions and Organizations across Nations, 2nd ed.; SAGE Publications: Thousand Oaks, CA, USA, 2001.

48. Van den Berg, P.T.; Wilderom, C.P.M. Defining, measuring, and comparing organisational cultures. Appl. Psychol. 2004, 53, 570-582. [CrossRef]

49. Smith, C. Organizational culture in practice. Hum. Resour. Dev. Int. 2000, 3, 153-158. [CrossRef]

50. Christensen, E.W.; Gordon, G.G. An exploration of industry, culture and revenue growth. Organ. Stud. 1999, 20, 397-422. [CrossRef]

51. Fellows, R.; Liu, A. Impact of behavioural compatibility on project procurement. In Perspectives on Culture in Construction; CIB Report No., 275; Fellows, R.F., Seymour, D.E., Eds.; CIB Publications: Delft, The Netherlands, 2002.

52. Kostova, T. Transnational transfer of strategic organizational practices: A contextual perspective. Acad. Manag. Rev. 1999, 24, 308-324.

53. Belassi, W.; Tukel, O.I. A new framework for determining critical success/failure factors in projects. Int. J. Proj. Manag. 1996, 14, 141-151. [CrossRef]

54. Hampden-Turner, C. Corporate Culture; Piatkus: London, UK, 1994.

55. Pinto, J.K. Project Management: Achieving Competitive Advantage, 4th ed.; Pearson Education: Harlow, UK, 2016.

56. Denison, D.R. Organizational culture: Can it be a key lever for driving organizational change. In The Handbook of Organizational Culture; Cartwright, S., Cooper, C., Eds.; John Wiley \& Sons: London, UK, 2000.

57. Olanipekun, A.O.; Abiola-Falemu, J.O.; Aje, I.O. Dimensions of organisational culture in quantity surveying firms in Nigeria. Australas. J. Constr. Econ. Build. 2014, 14, 54-70. [CrossRef]

58. Bettinger, C. Use corporate culture to trigger high performance. J. Bus. Strategy 1989, 10, 38-42. [CrossRef] [PubMed]

59. Hansen, G.S.; Wernerfelt, B. Determinants of firm performance: The relative importance of economic and organizational factors. Strat. Mgmt. J. 1989, 10, 399-411. [CrossRef]

60. Denison, D.R. Corporate Culture and Organizational Effectiveness; Wiley: New York, NY, USA, 1990.

61. Liu, A.M.M. Culture in the Hong Kong real-estate profession: A trait approach. Habitat Int. 1999, $23,413-425$. [CrossRef]

62. Khan, I.U.; Usoro, A.; Majewski, G.; Kuofie, M. An organisational culture model for comparative studies: A conceptual view. Int. J. Global Bus. 2010, 3, 53-82.

63. Kessel, F.G.A.V.; Oerlemans, L.A.G.; van Stroe-Biezen, S.A.M. No creative person is an island: Organisational culture, academic project-based creativity, and the mediating role of intraorganisational social ties. S. Af. J. Econ. Manag. Sci. 2014, 17, 46-69.

64. Uher, T.E.; Loosemore, M. Essentials of Construction Project Management; University of New South Wales Press: Sydney, Australia, 2004.

65. Hofstede, G. The cultural relativity of organizational practices and theories. J. Int. Bus. Stud. 1983, 14, 75-89. [CrossRef]

66. Harrison, R. Understanding your organisation's character. Harv. Bus. Rev. 1972, 50, 119-128.

67. Handy, C.B. Understanding Organizations, 3rd ed.; Penguin Books: Harmondsworth, UK, 1985.

68. Bryde, D.J.; Robinson, L. Client versus contractor perspectives on project success criteria. Int. J. Proj. Manag. 2005, 23, 622-629. [CrossRef]

69. Deal, T.E.; Kennedy, A.A. Corporate Cultures: The Rites and Rituals of Corporate Life; Addison-Wesley Publishing Company: Reading, MA, USA, 1982.

70. Thompson, J.L. Strategic Management: Awareness and Change; Chapman \& Hall, University and Professional Division: London, UK, 1993. 
71. Egan, J. Rethinking Construction; Department of the Environment, Transport and the Regions HMSO: London, UK, 1998.

72. Quinn, R.E. Beyond Rational Management: Mastering the Paradoxes and Competing Demands of High Performance; Jossey-Bass: San Francisco, CA, USA, 1988.

73. Low, S.P.; Shi, Y. Cultural influences on organizational processes in international projects: Two case studies. Work Study 2001, 50, 276-285.

74. Gasik, S. A model of project knowledge management. Proj. Manag. J. 2011, 42, 23-44. [CrossRef]

75. Pillai, A.S.; Joshi, A.; Rao, K.S. Performance measurement of R\&D projects in a multi-project, concurrent engineering environment. Int. J. Proj. Manag. 2002, 20, 165-177.

76. Kagioglou, M.; Cooper, R.; Aouad, G. Performance management in construction: A conceptual framework. Constr. Manag. Econ. 2001, 19, 85-95. [CrossRef]

77. Carvalho, M.M.; Rabechini, R.J. Impact of risk management on project performance: The importance of soft skills. Int. J. Prod. Res. 2015, 53, 321-340. [CrossRef]

78. Todorović, M.L.; Petrović, D.Č.; Mihić, M.M.; Obradović, V.L.; Bushuyev, S.D. Project success analysis framework: A knowledge-based approach in project management. Int. J. Proj. Manag. 2015, 33, 772-783. [CrossRef]

79. Westerveld, E. The project excellence model@: Linking success criteria and critical success factors. Int. J. Proj. Manag. 2003, 21, 411-418. [CrossRef]

80. Diallo, A.; Thuillier, D. The success dimensions of international development projects: The perceptions of African project coordinators. Int. J. Proj. Manag. 2004, 22, 19-31. [CrossRef]

81. Xiao, H.; Proverbs, D. The performance of contractors in Japan, the UK and the USA. Int. J. Qual. Reliab. Manag. 2002, 19, 672-687. [CrossRef]

82. Baloi, D.; Price, A.D.F. Modelling global risk factors affecting construction cost performance. Int. J. Proj. Manag. 2003, 21, 261-269. [CrossRef]

83. Lim, C.S.; Mohamed, M.Z. Criteria of project success: An exploratory re-examination. Int. J. Proj. Manag. 1999, 17, 243-248. [CrossRef]

84. Sawacha, E.; Naoum, S.; Fong, D. Factors affecting safety performance on construction sites. Int. J. Proj. Manag. 1999, 17, 309-315. [CrossRef]

85. Cox, R.F.; Issa, R.R.A.; Ahrens, D. Management's perception of key performance indicators for construction. J. Constr. Eng. Manag. 2003, 129, 142-151. [CrossRef]

86. Chan, A.P.C.; Chan, A.P.L. Key performance indicators for measuring construction success. Benchmarking 2004, 11, 203-221. [CrossRef]

87. Liu, A.M.M.; Shuibo, Z.; Meiyung, L. A framework for assessing organisational culture of Chinese construction enterprises. Eng. Constr. Archit. Manag. 2006, 13, 327-342. [CrossRef]

88. Wong, P.S.P.; Cheung, S.O.; Leung, K.Y. Moderating effect of organizational learning type on performance improvement. J. Manag. Eng. 2008, 24, 162-172. [CrossRef]

89. Atkinson, R. Project management: Cost, time and quality, two best guesses and a phenomenon, its time to accept other success criteria. Int. J. Proj. Manag. 1999, 17, 337-342. [CrossRef]

90. Bassioni, H.A.; Price, A.D.F.; Hassan, T.M. Building a conceptual framework for measuring business performance in construction: An empirical evaluation. Constr. Manag. Econ. 2005, 23, 495-507. [CrossRef]

91. Alarcon-Cardenas, L.F.; Ashley, D.B. Project Performance Modeling: A Methodology for Evaluating Project Execution Strategies; University of California: Berkeley, CA, USA, 1992.

92. Kululanga, G.K.; Edum-Fotwe, F.T.; McCaffer, R. Measuring construction contractors' organizational learning. Build. Res. Inf. 2001, 29, 21-29. [CrossRef]

93. Luu, T.V.; Kim, S.Y.; Cao, H.L.; Park, Y.M. Performance measurement of construction firms in developing countries. Constr. Manag. Econ. 2008, 26, 373-386. [CrossRef]

94. Lam, E.W.M.; Chan, A.P.C.; Chan, D.W.M. Benchmarking the performance of design-build projects: Development of project success index. Benchmarking 2007, 14, 624-638. [CrossRef]

95. Hair, J.F.; Tatham, R.L.; Anderson, R.E.; Black, W. Multivariate Data Analysis; Prentice Hall: Englewood Cliffs, NJ, USA, 1998.

96. Sharma, S.; Mukherjee, S. Applied Multivariate Techniques; John Wiley \& Sons Canada, Limited: New York, NY, USA, 1996. 
97. Pallant, J. SPSS Survival Manual: A Step by Step Guide to Data Analysis Using the SPSS Program, 12th ed.; Allen and Unwin: Crows Nest, Australia, 2005.

98. Prost, L.; Makowski, D.; Jeuffroy, M.-H. Comparison of stepwise selection and Bayesian model averaging for yield gap analysis. Ecol. Model. 2008, 219, 66-76. [CrossRef]

99. Viallefont, V.; Raftery, A.E.; Richardson, S. Variable selection and Bayesian model averaging in case-control studies. Stat. Med. 2001, 20, 3215-3230. [CrossRef] [PubMed]

100. Wang, D.; Zhang, W.; Bakhai, A. Comparison of Bayesian model averaging and stepwise methods for model selection in logistic regression. Stat. Med. 2004, 23, 3451-3467. [CrossRef] [PubMed]

101. Field, A.P. Discovering Statistics Using SPSS for Windows: Advanced Techniques for the Beginner; SAGE: London, UK, 2000.

102. Cheung, S.O.; Wong, P.S.P.; Wu, A.W.Y. Towards an organizational culture framework in construction. Int. J. Proj. Manag. 2011, 29, 33-44. [CrossRef]

103. Das, T.K.; Teng, B.-S. Between trust and control: Developing confidence in partner cooperation in alliances. Acad. Manag. Rev. 1998, 23, 491-512.

104. Hutchinson, A.; Gallagher, J. Project Alliances: An Overview; Alchimie Pty Ltd., Phillips Fox Lawyers: Melbourne, Australia, 2003.

105. Maxwell, J.R. Management of employee empowerment. J. Organ. Cult. Commun. Confl. 2005, 9, 61.

106. Fellows, R.F.; Langford, D.; Newcombe, R.; Urry, S. Construction Management in Practice; Blackwell Publishing House Science: Oxford, UK, 2002.

107. Pearce, D.W. The Social and Economic Value of Construction: The Construction Industry's Contribution to Sustainable Development; nCRISP: London, UK, 2003.

108. Chan, A.P.C.; Scott, D.; Lam, E.W.M. Framework of success criteria for design/build projects. J. Manag. Eng. 2002, 18, 120-128. [CrossRef]

109. Leung, M.Y.; Ng, S.T.; Cheung, S.O. Measuring construction project participant satisfaction. Constr. Manag. Econ. 2004, 22, 319-331. [CrossRef]

110. Groemping, U. Relative importance for linear regression in R: The package relaimpo. J. Stat. Softw. 2006, 17, $1-27$.

111. Fetterman, D.M. Empowerment evaluation. In International Encyclopedia of the Social E Behavioral Sciences; Wright, J.D., Ed.; Elsevier Science: Amsterdam, The Netherlands, 2015.

112. Christenson, D.; Walker, D.H.T. Understanding the role of "vision" in project success. IEEE Eng. Manag. Rev. 2004, 32, 57-73. [CrossRef]

113. Latham, M. Constructing the Team, Final Report of the Joint Government/Industry Review of Procurement and Contractual Arrangements in the United Kingdom Construction Industry; HMSO: London, UK, 1994.

114. Drew, D. Competing in construction auctions: A theoretical perspective. In Modern Construction Economics: Theory and Application; Valence, G.D., Ed.; SPON Press: London, UK, 2011; pp. 63-79. 